Magelaran: Jurnal Pendidikan Seni, Vol 4. No. 2, Desember 2021, ISSN: 2620-8598

\title{
Komparasi Kostum Kesenian Pontrangan Di Kampung Salawe Desa Cimaragas Kecamatan Cimaragas Kabupaten Ciamis Dan Kesenian Jurig Sarengseng Dari Desa Binangun Kota Banjar
}

\author{
Hutman Abdillah, Asti Tri Lestari, Denden Setiaji \\ Prodi Sendratasik Fakultas Keguruan dan Ilmu Pendidikan, Universitas Muhammadiyah Tasikmalaya, J. \\ Tamansari No. KM 2.5 Mulyasari Kec. Tamansari Tasikmalaya Jawa Barat Indonesia \\ Email: Hutmanabdillah@gmail.com
}

\begin{abstract}
Comparison is a method that aims to find similarities and differences between two or more variables with the aim of determining or knowing the similarities and differences of these variables. Costumes other than functioning as body armor, costumes can also be used as a picture of the wearer and a good costume is one that has meaning in it. Pontrangan art is a regional art whose pioneering was carried out in early 2014 and performed in 2015 and has been recognized by the Ciamis Regency government as a typical art from Cimaragas Village. And Jurig Sarengseng art is one of the arts from Banjar City but borders Ciamis Regency which was originally shown in 2013 and has been recognized by the Banjar City government. The purpose of this study is to compare the process of making costumes for the two arts and what meanings are contained in the clothes and accessories of the two arts. This research method is a descriptive method with a qualitative approach. Data collection techniques used are observation, interviews and documentation studies. The object under study is the parts contained in the costumes of Art of Pontrangan and Art of Jurig Sarengseng and the subjects in this study are informants or resource persons who know about the object of research. The results of the study show the process of making or forming the Art of Pontrangan and Art of Jurig Sarengseng from masks, clothes, dolls and accessories used by female dancers so that it is said to be Pontrangan art and Jurig Sarengseng art. Next, compare the meanings contained in the costumes of the Art of Pontrangan and the Arts of Jurig Sarengseng, from the masks, the clothes of the art dolls to the accessories worn.

Keywords: Comparison, Costume, Pontrangan, Jurig Sarengseng
\end{abstract}

\begin{abstract}
Abstrak
Komparasi merupakan metode yang bertujuan untuk mencari persamaan dan perbedaan antara dua variable atau lebih dengan tujuan untuk menentukan atau mengetahui kesamaan dan perbedaan dari variable-variabel tersebut. Kostum selain berfungsi sebagai pelindung badan, kostum juga bisa dijadikan sebagai gambaran dari pemakainya dan kostum yang baik yaitu yang memiliki makna didalammnya. Kesenian Pontrangan adalah kesenian daerah yang perintisannya dilakukan sejak awal tahun 2014 dan dipertunjukan pada tahun 2015 serta telah diakui oleh pemerintah Kabupaten Ciamis sebagai kesenian khas dari Desa Cimaragas. Dan kesenian Jurig Sarengseng merupakan salah satu kesenian dari Kota Banjar namun berbatasan dengan Kabupaten Ciamis yang awal dipertunjukan pada tahun 2013 serta telah diakui oleh pemerintah Kota Banjar. Tujuan dari penelitian ini yaitu untuk mengkomparasikan proses pembuatan kostum kedua kesenian tersebut dan makna apa yang terkandung dalam pakaian dan aksesoris kedua kesenian tersebut. Metode penelitian ini adalah metode deskriptif dengan pendekatan kualitatif. Teknik pengumpulan data yang digunakan adalah observasi, wawancara dan studi dokumentasi. Objek yang diteliti adalah bagian-bagian yang terdapat pada kostum Kesenian Pontrangan dan Kesenian Jurig Sarengseng dan subjek dalam penelitian ini adalah informan atau narasumber yang mengetahui tentang objek penelitian. Hasil penelitian menunjukan proses pembuatan atau terbentuknya Kesenian Pontrangan dan Kesenian Jurig Sarengseng dari mulai topeng, baju, boneka serta aksesoris yang digunakan oleh penari wanita sehingga dikatakan sebagai kesenian Pontrangan dan Kesenian Jurig Sarengseng. Selanjutnya mengkomparasikan makna apa yang terkandung dalam kostum Kesenian Pontrangan dan Kesenian Jurig Sarengseng dari mulai topeng, baju boneka kesenian hingga aksesoris yang dikenakan.

Kata Kunci: Komparasi, Kostum, Pontrangan, Jurig Sarengseng
\end{abstract}


Magelaran: Jurnal Pendidikan Seni, Vol 4. No. 2, Desember 2021, ISSN: 2620-8598

\section{A. Pendahuluan}

1. Latar Belakang Masalah

Kabupaten Ciamis merupakan salah satu daerah yang memiliki banyak ragam kesenian seperti Wayang Kidung dari Lakbok, Karinding Nyengsol dari Kawali, Gondang Buhun dari Tambaksari dan masih banyak lagi. Kesenian-kesenian tersebut memiliki keunikan dan ciri khas tersendiri dan pesanpesan yang biasanya menggambarkan keadaan atau kebiasaan pribumi.

Salah satu kesenian yang cukup menarik dari daerah Ciamis yaitu Kesenian Pontrangan. Kata pontrangan sendiri berasal dari kata "pontrang" yang artinya tempat nasi yang terbuat dari anyaman daun kelapa yang masih hijau. Hal yang paling menarik dari kesenian tersebut yaitu dari pakaian dan penutup kepala atau topeng yang di gunakan. Dengan berbagai macam motif dan bentuk ekpresi dari topeng pontrangan tersebut menjadi daya tarik tersendiri dan menarik untuk di lihat. Namun seiring berjalannya waktu, kini kesenian tersebut sedikit mulai tergeser karena kemajuan zaman dan teknologi yang memudahkan masuknya budaya luar atau budaya barat sehingga mempengaruhi pengetahuan masyarakat tentang kesenian pontrangan.

Kostum atau busana adalah pakaian yang kegunaannya selain digunakan sebagai pelindung badan, kostum juga merupakan salah satu bagian yang akan di lihat pertama kali serta kostum merupakan barang penting dalam kehidupan. Kostum memiliki peran luas. Selain dijadikan kebiasaan dari daerah tertentu, kostum juga dapat dipergunakan dalam suatu pertunjukan. Kostum juga biasanya menyesuaikan dengan kebutuhan peranannya.

Kesenian Pontrangan memiliki beberapa unsur didalamnya seperti pencak silat yang diiringi oleh music-musik tradisional seperti bangbaraan dan alat pukul lainnya. Kesenian ini biasanya rutin dipentaskan dalam upacara adat Misalin dan sering dipertunjukan juga dalam beberapa acara penting lainnya. Dalam kesenian pontrangan ini terdapat beberapa kelengkapan yaitu pakaian, topeng serta beberapa properti seperti pontrang.

Dalam penelitian ini, penulis memfokuskan pada segi kostum dari pembuatan serta makna pakaian dan aksesorisnya. Saat dilakukannya penelitian, penulis menemukan skripsi dengan fokus penelitian yang sama namun objek yang diteliti berbeda yaitu mengenai makna simbolik kostum Kesenian Jurig Sarengseng yang ditulis oleh Fahmi Firdaus pada tahun 2019 di Desa Binangun Kecamatan Pataruman Kota Banjar.

Kedua kesenian tersebut dirasa sangat menarik dan layak untuk dikomparasikan. Hal tersebut dapat dilihat dari kostum yang dikenakan kedua kesenian tersebut salah satunya seperti kesenian pontrangan yang pakaiannya secara keseluruhan menggunakan daun kelapa yang dianyam dan kesenian jurig sarengseng yang hampir seluruh badan diselimuti oleh ujung bambu (sarengseng). Ciri khas dari kedua kesenian tersebutlah yang membuat penulis tertarik untuk melakukan penelitian. Selain penulis juga pernah ikut berpartisipasi secara langsung dalam pementasan kesenian pontrangan pada tahun 2015, kedua kesenian tersebut juga sudah diakui oleh pemerintah daerah dan sudah mendapatkan beberapa penghargaan dan keduanya merupakan sebuah kesenian bebegig atau orangorangan sehingga, hal ini layak untuk dilakukannya studi komparasi karena 
memiliki beberapa persamaan dan perbedaan didalamnya.

Melihat kondisi tersebut, maka peneliti menarik kesimpulan untuk mengkomparasikan kedua kesenian bebegig tersebut sebagai objek penelitian dalam karya ilmiah penulis yang bejudul "Komparasi Kostum Kesenian Pontrangan di Kampung Salawe, Desa Cimaragas, Kecamatan Cimaragas, Kabupaten Ciamis dan Kesenian Jurig Sarengseng dari Desa Binangun, Kota Banjar".

2. Identifikasi Masalah

a. Makna yang terkandung didalam kostum kesenian tersebut.

b. kurangnya pelaku seni akademi dalam pelestarian kesenian tersebut.

\section{Rumusan Masalah}

Berdasarkan latar belakang dan inti persoalan dalam upaya mengungkapkan bentuk dan makna dari kesenian tradisional keduanya, penulis memfokuskan dan merumuskan masalah utamanya sebagai berikut:

"Bagaimana proses pembuatan kostum Kesenian Pontrangan di Kampung Salawe Desa Cimaragas Kecamatan Cimaragas Kabupaten Ciamis dan Kesenian Jurig Sarengseng dari Desa Binangun Kota Banjar.

\section{Tujuan Penelitian}

Adapun yang menjadi tujuan dalam penelitian ini adalah untuk menjawab beberapa permasalahan yang ada dalam penelitian ini yaitu Mendeskrifsikan pembuatan kostum Kesenian Pontrangan di Kampung Salawe Desa Cimaragas Kecamatan Cimaragas Kabupaten Ciamis dan Kesenian Jurig Sarengseng dari Desa Binangun Kota Banjar.
B. Pembahasan

1. Landasan Teori

a. Komparasi

Komparasi adalah suatu metode yang digunakan untuk membandingkan data-data yang di tarik kedalam konklusi baru. Komparasi sendiri berasal dari bahasa inggris yaitu Compare yang artinya membandingkan untuk menemukan persamaan dari kedua konsep atau lebih. Menurut Winarno Surakhmad (1986:84) menyebutkan:

"Komparasi adalah penyelidikan deskriptif yang berusaha mencari pencerahan melalui analisis tentang hubungan sebab akibat, yakni memilih factor-faktor tertentu yang berhubungan dengan situasi atau fenomena yang di selidiki dan membandingkan satu faktor dengan faktor lain."

\section{b. Kostum}

Kostum atau busana adalah pakaian yang kegunaannya selain digunakan sebagai pelindung badan, kostum juga merupakan salah satu bagian yang akan di lihat pertama kali serta kostum merupakan barang penting dalam kehidupan. Menurut Kamus Besar Bahasa Indonesia (2013:634) dijelaskan bahwa:

"Kostum ialah pakaian khusus atau pula dikatakan sebagai seragam bagi perseorangan, regu, rombongan dan sebagainya dalam bentuk upacara, pertunjukan dan lain-lain. Kostum dapat merujuk pada pakaian secara umum atau gaya pakaian tertentu pada orang, kelas masyarakat, atau periode tertentu yang bertujuan untuk 
penekanan pada karakter atau tipe karakter, yang masing-masing akan membedakan pemakaiannya dengan yang lain, pada suatu pertunjukan teatrikal".

Jadi, bawasannya dalam pembuatan kostum hal utama yang harus diperhatikan yaitu mengenai makna dan kegunaannya. Kostum yang baik juga memiliki kegunaan lain bukan hanya sekedar penutup badan, kostum juga sebaiknya disesuaikan dengan kebutuhannya.

\section{c. Makna}

Makna dapat diartikan sebagai arti yang didalamnya memiliki hubungan antara lambang dengan acuannya. Menurut Dewa dan Rohmadi dalam (Rina Nurjannah 2013:5) menyebutkan bahwa "Makna merupakan konsep abstrak pengalaman manusia, tetapi bukanlah pengalaman perorangan".

Sedangkan menurut Santoso (2006: 10) menyebutkan

"Makna adalah konsep, gagasa, ide atau peringatan yang berada secara padu bersama satuan kebahasaan yang menjadi penanda yaitu kata, frasa dan kalimat.

Dari kedua uraian diatas dapat dijelaskan bahwa makna merupakan suatu konsep, ide atau gagasan pengalaman manusia yang yang menjadi tanda berupa kata, frasa dan kalimat.

\section{d. Warna}

Dalam kehidupan manusia, warna sudah tidak aneh lagi dan selalu digunakan dalam banyak hal. Warna merupakan penanda alami yang tidak dapat hilang karena, warna adalah sebagian dasar dari semua yang ada di alam semesta.

Menurut Dharsono (2017: 46)

"Warna sebagai salah satu elemen atau medium seni rupa, merupakan unsur yang sangat penting, baik di bidang seni rupa murni maupun terapan, warna sebagai representasi alam, warna sebagai lambang/simbol dan sebagai ekspresi".

1) Psikologi warna

a) Putih

Menurut Darmaprawira (2002: 47) menyebutkan bahwa: "Warna putih memiliki karakter positif, merangsang, cemerlang, ringan, dan sederhana. Putih melambangkan kesucian, polos, jujur, dan murni. Di Cina, warna putih melambangkan duka cita. Putih melambangkan kekuatan maha tinggi, lambang cahaya, kemenangan yang mengalahkan kegelapan"

Dalam kutipan tersebut disebutkan bahwa warna putih memiliki makna yang luas dan dominan bersifat baik. Tetapi terdapat makna yang buruk juga didalamnya.

b) Hitam

Menurut Darmaprawira (2002: 48) menjelaskan bahwa:

"Warna hitam melambangkan kegelapan dan ketidakhadiran cahaya. Hitam mendandakan kekuatan yang gelap, lambang misteri, warna malam, dan selalu diindikasikan dengan kebalikan dari sifat waarna putih atau berlawanan dengan cahaya terang. Sering juga dilambangkan sebagai warna kehancuran, atau kekeliruan. Umumnya warna hitam diasosiasikan dengan sifat negatif. Tetapi warna hitam juga dapat menunjukan sifat-sifat yang positif, yaitu menandakan 
sikap tegas, kukuh, formal, struktur yang kuat”.

Dari pernyataan tersebut sangat jelas, warna hitam adalah wana yang digambarkan negatif atau menjurung pada kejelekan. Karena warna hitam dikatakan sebagai warna yang negatif, maka disebutkan juga bahwa warna hitam merupakan kebalikan dari warna putih.

c) Hijau

Karakteristik dan simbolisasi warna hijau menurut Darmaprawira (2002: 46)

"Warna hijau mempunyai karakter yang hampir sama dengan biru. Hijau melambangkan perenungan, kepercayaan (agama), dan keabadian. Dalam penggunaan biasa warna hijau mengungkapkan kesegaran, mentah, muda, belum dewasa, pertumbuhan, kehidupan dan harapan, kelahiran kembali dan kesuburan".

Dengan begitu, warna hijau adalah warna yang lebih natural. Karena warna putih memiliki pemaknaan yang hidup atau alamiah dan bersih.

\section{e. Kesenian Pontrangan}

Kata Pontrangan itu berasal dari kata "pontrang" yang merupakan wadah nasi yang terbuat dari daun kelapa muda. Nama pontrangan tersebut diciptakan oleh Abah Latif yang merupakan sesepuh atau juru kunci dari Situs Galuh Midang Salawe. Sebelum nama kesenian pontrangan disahkan, nama kesenian ini mengalami beberapa perubahan yang dari awalanya bernama manusia pontrang hingga berubah menjadi Pontrangan. Menurut Anjani (2019:6) menyebutkan bahwa:

"Kesenian pontrangan merupakan kesenian tradisional dari daerah Cimaragas, Ciamis, Jawa barat. Kesenian pontrangan biasanya terdiri dari ikon bebegig dan ada unsur Kuda lumpingnya serta diiringi oleh kesenian alat musik bangbaraan. Kesenian ini sering di pentaskan atau di pertunjukan dalam kegiatan terutama ketika pelaksanaan Ritual Misalan".

\section{f. Kesenian Jurig Sarengseng}

Kata Jurig Sarengseng berasal dari dua kata yaitu Jurig dan Sarengseng. Jurig yaitu gambaran suatu makhluk atau sosok manusia yang serakah, seram, jahat dan suka merusak alam. Sedangkan Sarengseng merupakan nama dari bagian ujung bambu (merang) yang tajam dan berbahaya. Jurig Sarengseng merupakan kesenian yang menggunakan bahan dasar limbah alam dalam pembuatan kostumnya seperti bambu, kayu dan injuk. Menurut Firdaus (2019:32)

"Pemain kesenian Jurig Sarengseng harus ber-makeup hitam yang memberi arti bahwa akibat kemajuan jaman sekarang ini banyak generasi muda yang kebablasan dalam pergaulan nya, dengan make up hitam menghimbau generasi muda untuk belajar mamilah dan memilih pergaulan sehingga tidak terjerumus kepada hal yang negatif". 


\section{Hasil Penelitian}

1. Proses pembuatan topeng
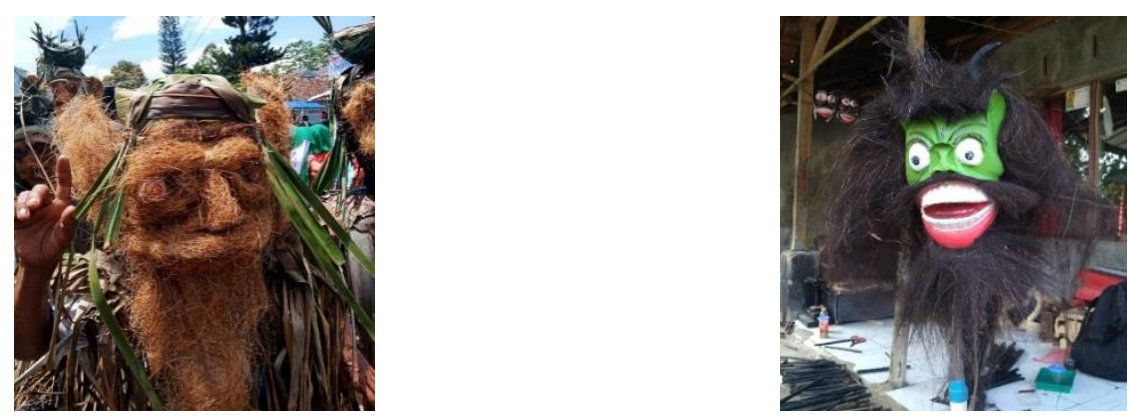

\begin{tabular}{|c|c|}
\hline Persamaan & Perbedaan \\
\hline $\begin{array}{l}\text { - Bentuk mata dan mulut hampir } \\
\text { sama }\end{array}$ & $\begin{array}{l}\text { - Bahan dasar topeng Kesenian } \\
\text { Pontrangan menggunakan sabut } \\
\text { kelapa sedangkan topeng kesenian } \\
\text { Jurig Sarengseng menggunakan Kayu } \\
\text { Lame. } \\
\text { - Alat yang digunakan untuk membuat } \\
\text { topeng Jurig Sarengseng lebih banyak } \\
\text { - Cat digunakan dalam membuat topeng } \\
\text { Jurig sarengseng sedangkan topeng } \\
\text { Kesenian Pontrangan tidak } \\
\text { menggunakan cat. } \\
\text { - Bahan untuk membuat topeng } \\
\text { kesenian Pontrangan hanya } \\
\text { menggunakan sabut kelapa } \\
\text { sedangkan topeng Jurig Sarengseng } \\
\text { memerlukan beberapa bahan dalam } \\
\text { pembuatannya. }\end{array}$ \\
\hline
\end{tabular}




\section{Proses pembuatan pakaian}
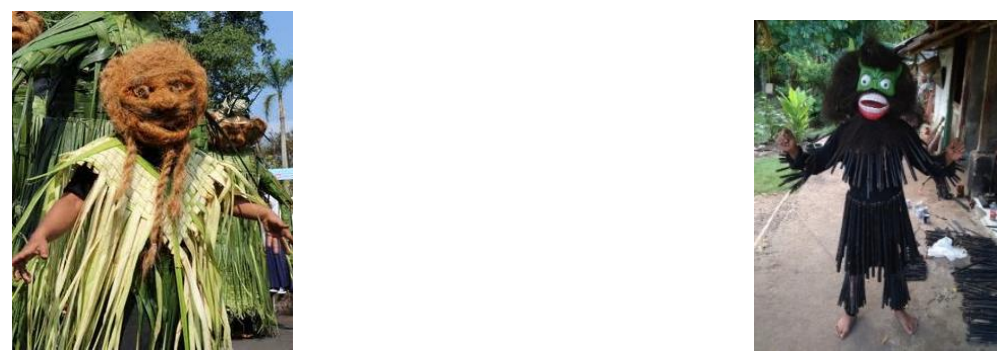

\begin{tabular}{|c|c|}
\hline Persamaan & Perbedaan \\
\hline $\begin{array}{l}\text { - Dalaman baju menggunakan } \\
\text { pakaian pangsi atau pakaian } \\
\text { seragam hitam } \\
\text { - Membutuhkan waktu kurang lebih } \\
\text { dua hari }\end{array}$ & $\begin{array}{l}\text { - } \text { Bahan utama pembatan pakaian } \\
\text { kesenian Pontrangan menggunakan } \\
\text { daun kelapa sedangkan kesenian Jurig } \\
\text { Sarengseng menggunakan ujung } \\
\text { bamboo. } \\
\text { - Kesenian } \\
\text { menggunakan cat dalam pewarnaan } \\
\text { kostum sedangkan kesenian Jurig } \\
\text { Sarengseng menggunakan cat hitam. } \\
\text { - Alat yang digunakan dalam } \\
\text { pembuatan kostum kesenian } \\
\text { pontrangan lebih sedikit daripada } \\
\text { kesenian Jurig Sarengseng. }\end{array}$ \\
\hline
\end{tabular}

\section{Kesimpulan}

Berdasarkan

penelitian

dan penglihatan mengenai Komparasi proses pembuatan dan makna kostum kesenian Jurig Sarengseng dan Kesenian Pontrangan dapat disimpulkan

1. Komparasi pembuatan kostum kesenian Jurig Sarengseng dan Kesenian Pontrangan

2. Komparasi proses pembuatan topeng kesenian Jurig Sarengseng dan Kesenian Pontrangan.

Dalam proses pembuatan topeng kesenian Jurig Sarengseng dan kesenian Pontrangan memiliki perbedaan yang signifikan terutama dibagian bahan dan alat yang digunakan. Dalam pembuatan topeng kesenian Pontrangan, bahan yang digunakan hanya sabut kelapa dan alat yang digunakan cukup dengan menggunakan lem untuk merekatkan bagian-bagian komponen wajah. Sedangkan, dalam pembuatan topeng kesenian Jurig Sarengseng menggunakan bahan utama kayu lame dan ijuk serta alat-alat yang digunakan dalam pembuatannya membutuhkan alat-alat yang terbilang banyak dan menggunakan beberapa mesin otomatis seperti mesin bor dan mesin sugu. 
Magelaran: Jurnal Pendidikan Seni, Vol 4. No. 2, Desember 2021, ISSN: 2620-8598

Hal yang sama dari kedua topeng tersebut yaitu dari ekspresi pada topeng yaitu memiliki ekspresi tersenyum.

3. Komparasi proses pembuatan kostum kesenian Jurig Sarengseng dan Kesenian Pontrangan.

Dalam pembuatan kostum kesenian Jurig Sarengseng dan Pontrangan juga memiliki persamaan dan perbedaan. Persamaannya yaitu dalam pembuatan kedua kostum tersebut hanya membutuhkan satu bahan utama yaitu kesenian Pontrangan memerlukan janur atau daun kelapa muda dan kesenian Jurig Sarengseng juga hanya memerlukan ujung bambu atau sarengseng sebagai bahan utama. Pembeda dari pembuatan kedua kostum tersebut yaitu dari segi alat yang digunakan. Kesenian Pontrangan tidak menggunakan cat, sedangkan kesenian Jurig Sarengseng menggunakan cat hitam untuk mewarnai sarengseng.

\section{Daftar Pustaka}

Darmaprawira, Sulasmi. 2001. Teori dan Kreativitas Penggunaannya Edisi ke 2. Bandung: Penerbit ITB.

Endang, Dais E. 2019. Komparasi Visual Properti Kesenian Kuda Lumping di Kampung Sidosari Desa Cipanas Kecamatan Cipatujah Kabupaten Tasikmalayadan Kuda Lumping di Kampung Kebon Waru Desa Gunung Batu Kecamatan Ciracap. Skripsi S1 Universitas Muhammadiyah Tasimalaya. Tidak diterbitkan.

Anjani, Yustin. 2019. Perkembangan Kesenian Pontrangan. Skripsi S1 Universitas Siliwangi. Tidak diterbitkan.

Firdaus, Fahmi . 2019. Makna Simbolik Kostum Kesenian Jurig Sarengseng Desa Binangun Kota Banjar. Skripsi S1 Universitas Muhammadiyah Tasikmalaya. Tidak diterbitkan.

Sugiyono. 2007. Metode Penelitian Kuantitatif, Kualitati fdan R\&D. Bandung: Alfabeta.

Sumardjo, Jakob. 2016. Filsafat Seni. Bandung: ITB Press

Sundara, Ade. 2013. Kesenian Bebegig Sukamantri Kabupaten Ciamis Pikeun Bahan Pangajaran Maca. Universitas Pendidikan Indonesia

Purwadi. 2007. Busana Jawa, Jenis-jenis Pakaian Adat, Sejarah, Nilai Filosofis dan Penerapannya. Yogyakarta: Pura Pustaka 